\title{
AN EMERGING POWERHOUSE IN EURASIAN GEOPOLITICS : THE SHANGHAI SIX+
}

\author{
Prof. Dr. Suat ÖKSÜZ, Ege University, Faculty of Economics and Administrative \\ Sciences, Department of International Relations, suat.oksuz@ege.edu.tr
}

\begin{abstract}
"Who rules East Europe commands the Heartland; who rules the Heartland commands the World-Island; who rules the World-Island controls the world." Halford J. Mackinder
\end{abstract}

\begin{abstract}
The paper is a study of a rather recent regional interstate formation in Asia, the Shanghai Cooperation Organization. Its background and progress is highlighted. With all indications, the organisation has caught the attention of researchers and will continue to occupy the agenda of the 21st century international politics. Bearing in mind the size and weight of its membership within the area it spans, the organisation is set to be a powerhouse to reckon with beyond its regional borders. After its structure is described, what the organisation implies for Russian and Chinese interests is taken up. The Organisation has significant implications for the Central Asian States and the neighboring countries. As an institutional actor in the global game, its regional and global implications are highlighted.
\end{abstract}

Key Words: regional cooperation, geopolitics, security, energy, Central Asia.

\section{INTRODUCTION}

Regional formations of power have attributes of geopolitics. Sometimes used as a synonym for political geography, geopolitics is a concept now commonly used to analyze global or regional power rivalries as well as the space dimensions of global political power distribution. It is hardly surprising that this very concept, which seemed largely to stay in shadows, has gained a prominent profile in the paradigm of international relations and mainstream media in the aftermath of Cold War. As he is viewed as the founder of the school of 
geopolitics, Halford J. Mackinder's pivotal work 'The Geographical Pivot of History' published in the Geographical Journal in 1904 should be given due credit. This most celebrated study of Mackinder is largely conceived as a pioneering work for signifying the distinct influence of geography upon politics. As aptly stated by Kennedy (2004), "the significance of Mackinder's paper was several fold; it not only pointed to the significance of distance/terrain/climate in shaping the conduct of international relations, but it also enjoyed a predictive value and designated the direction of world history against the backdrop of what Mackinder $(1904,421)$ termed 'the end of a great historic epoch'".

It was surely after of the disintegration of the Soviet Union in 1991 and hence with the emergence of independent states that the Central Asian geography really crystallized as a concrete case in the application of Mackinder's ideas. It was coined 'Who controls the Silk Road (routes of pipelines) controls the world' (Robbins 1994, 43). Since then, one can observe in an astonishing way how his ideas and unfolding events have instigated store of writings in literature on Central Asia. Expanded Central Asia forms the 'geopolitical pivot' in the Eurasian space, which houses almost $2 / 3$ of the world's population and currently accounts for around 50 percent of the world gross domestic product. As Brzezinski (1997) highlighted, Eurasia, which has the majority of underground riches, thus became the chess board for future fights among great powers when the Soviet Union lost its hegemonic power in this region (Brzezinski,1997; Weitz, 2006). The region commonly termed 'Central Asia' in recent literature covers an area of four million square kilometres bordered by the Caspian Sea in the west, Afghanistan, Iran, and Pakistan to the south, the Taklamakan desert, or China in the east, and Russian Siberian steppes to the north (Polat, 2002; Linn and Tiomkin, 2005).

The region from Urals to shores of the China Sea is home to big powers and small nation states, and a few forms of regional alliances, notably led by Russia as remnants of the Soviet hegemony. In such diverse cultural, political, and economic environment, the mainland Asia accomodates not only a fairly new formation of alliance jointly built by two regional hegemonic powers, China (the Dragon) and Russia (the Bear), but also hosts an outside global power, the United States plus NATO. It is significant that the hegemonic power-broking will be orchestrated in this very heartland. In the words of Kennedy, 'Right now, with hundreds of thousands of US troops in the Eurasian rimlands and with an administration constantly explaining why it has to stay the course, it looks as if Washington is taking seriously Mackinder's injunction to ensure control of "the geographical pivot of history". Some of today's US neo-con intellectuals make admiring reference to former British rule in that region, and have called for the creation of a US "colonial office' (Kennedy, 2004). 


\section{SHIFT IN POWER EQUATION -AN ALLIANCE "MADE IN ASIA"}

As part of the balance of power game, the Shanghai Cooperation Organization (SCO), in terms of a formally constructed unit, spans the very heartland of Eurasia. What again makes the region important is beyond what is seen in the face of a company of two giants and associated outsiders, all endowed with nuclear arsenals. The region is divided quite evenly between countries possessing significant hydrocarbon resources (Russia, Iran, Kazakhstan, Azerbaijan, and Turkmenistan) and countries which direly need access to those resources (India, China, Pakistan, and the other nations neigbouring Caucasus). Given the intense current and prospective world demand for raw materials, the region's significantly known mineral resources and, if not markets, beckon foreign investment, exploration and technology.

The SCO was founded in 2001 by six Asian countries, China, Russia, Kazakhstan, Kyrgyzstan, Tajikistan and Uzbekistan. The Organization became the main vehicle for promoting confidence-building among Russia, China, and Central Asian countries. It is appearently built upon the 'spirit 'of its predecessor named 'the Shanghai Five'. All essentially evolved out of cooperation regarding border demilitarisation and security issues that began as early as 1987 between China and the USSR,. In the mid-1990s China, Russia, and several Central Asian countries resolved a series of border disputes, which ultimately led to the formation of a new multilateral security organization known as the "Shanghai Five". The Organisation became the main vehicle for promoting confidence-building among Russia, China, and Central Asian countries.(Plater-Zyberk, 2007; Germanovich, 2008; Sangtu, 2008).

The original 'Shanghai Five' was formed in 1996 as a forum to resolve old Soviet-Chinese border disputes-(Shanghai Agreement on Enhancing Military Trust in Border Regions (1996) and to facilitate the demilitarisation of the 4,600mile long border, that is, mutually reducing military forces in border regionsMoscow Agreement on Mutual Reduction of Forces in Border Regions (1997.). The signatories were heads of state of the Republic of Kazakhstan, the People's Republic of China, the Kyrgyz Republic, the Russian Federation and the Republic of Tajikistan. The summary documents were subsequently signed during their meetings in Alma-Ata (1998), Bishkek (1999), and Dushanbe (2000). These agreements were geared to confidence-building in the military sphere and to mutual reduction of military forces in border areas. In January 2001, Uzbekistan requested to join the Shanghai Five as a full member.

At the background, the organisation is a diplomatic innovation for China, the Dragon, which was traditionally isolationist and not much eager for multilateral associations. Initially contemplated as a confidence-building mechanism, the Organization has risen in stature and scope, making headlines in 2005 when, on July 5,2005 , the SCO issued a declaration implicitly calling for the United States to set a timeline for withdrawing its military forces from Karshi-Khanabad 
Air Base in southern Uzbekistan; which came in the aftermath of sharp criticisms from Washington, in response to the brutally supressed uprising in the Andijan province of Uzbekistan.

The 'Shanghai Five's transformation into the SCO happened at a summit in Shanghai on 15 June 2001 when the heads of those six countries (original five plus Uzbekistan) signed the Declaration on SCO establishment and the Shanghai Convention on combating terrorism, separatism and extremism. The stated aims of the SCO are spelled as to combat the "three evils" of terrorism, separatism, and extremism, as well as to promote various forms of cooperation among the member governments. The SCO emblem, marked "Shanghai Cooperation Organization" in Chinese and Russian respectively, is a round symbol composed mainly of a map of the six member states, with olive branches and two ribbons encircling it from both left and right, symbolizing peace and prosperity (the Organisation's web site http://www.sectsco.org).

Geographically, the SCO covers an area of over 30 million km square, or about three fifths of Eurasia, with a population of 1.455 billion, about a quarter of the world's total. The SCO's present members and observers account for some 2,7 billion people out of 6,4 billion of the world population. Should India, Iran, Pakistan and Mongolia join the Organisation, the demography and geography of Eurasia, from the Baltic to the Pacific, will be portrayed in the largest political, economic and military alliance, what some Western commentators call a 'NATO of the East'.

Among important indications of the SCO's growing recognition and participation in international stage one can mention, first of all, the eagerness displayed by some neighboring countries to join the Organisation; secondly, several current studies about the SCO have been published by American and European institutions as well as others in the post-2002 period; thirdly, it is the Organisation's acquisition of observer status at the UN General Assembly in December 2004. An increasing number of countries and international organizations have proposed to establish contacts and cooperation with the SCO. The SCO now maintains ongoing regular contacts with various UN bodies such as ESCAP and UNDP. In the course of 2005-2007, the SCO has proceeded to sign the Memoranda of Mutual Understanding (MoU) with other active institutional formations on the Eurasian space, namely, the OSCE, CIS, ASEAN CICA, and OCST, as well as the Dialogue of Cooperation in Asia (DCA), the Economic Cooperation Organization (ECO), the South Asian Association of Regional Cooperation (SAARC), the Asia-Pacific Economic Cooperation (APEC), the Eurasian Economic Cooperation (EurasEC) are also among these.

As reiterated in the Declaration on Fifth Anniversary of Shanghai Cooperation Organisation, (Shanghai, 15 June 2006), the SCO owes its smooth growth to its consistent adherence to the "Spirit of Shanghai" based on "mutual trust, mutual benefit, equality, consultations, respect for the diversity of cultures and aspiration towards common development". In accordance with the Declaration, 
"The members support each other in their principled positions on and efforts in safeguarding sovereignty, security and territorial integrity. They will not join any alliance or international organisation and not allow their territories to be used in any way that undermines the sovereignty, security and territorial integrity of other SCO member states. They prohibit activities by organisations or gangs in their territories that are detrimental to the interests of other member states. The SCO member states will continue to strengthen coordination and cooperation in international and regional affairs and take a common position on matters involving the SCO's interests. The SCO has the potential to play an independent role in safeguarding stability and security in this region. To comprehensively deepen cooperation in combating terrorism, separatism, extremism and drug trafficking is a priority area for the SCO. The SCO will make a constructive contribution to the establishment of a new global security architecture of mutual trust, mutual benefit, equality and mutual respect, What specific means and mechanisms should be adopted to safeguard security of the region is the right and responsibility of countries in the region".

On 14 September 2001, Almaty hosted the first meeting of heads of governments of SCO member states, who signed the Memorandum among the Governments of SCO Member States on Main Objectives and Directions of Regional Economic Cooperation. The meeting also endorsed the launch of a mechanism of regular meetings of heads of governments. At the summit of St Petersburg on 07 June 2002, the heads of states adopted the SCO Charter enshrining the goals, principles and main directions of cooperation within the Organisation. In addition to the adoption of the Charter, the summit also signed the 'Agreement among SCO Member States on the Regional Antiterrorist Structure'. On 23 September 2003, Beijing hosted a meeting of heads of governments of SCO member states, whereby they approved the Programme of Multilateral Trade and Economic Cooperation among SCO Member States and also adopted the Organisation's first budget for 2004.

At a session in Tashkent in 2004, the Heads of State Council approved The Regulations on Observer Status at the Shanghai Cooperation Organisation, composed of seventeen itemized points. Accordingly, Article 14 of the Organisation's Charter determines the order of granting observer status to an interested state or an intergovernmental international organisation (forum). During 2004 and 2005, Mongolia, India, Pakistan and Iran became observers in the organization. The Iranian President Mahmoud Ahmadinejad attended the Shanghai summit in 2006, there has been speculation that Iran might join the SCO. In March 2008, Iran's Foreign Minister Manouchehr Mottaki officially announced Iran's bid, saying Tehran had submitted a request for full membership to the SCO Secretariat. Belarus, Nepal and Sri-Lanka have expressed their intention as observers. Russian foreign minister Vitaly Vorobyov even once commented that Afghanistan may be granted observer status in the Organization (Novosti Russian News and Information Agency, $7 / 6 / 2005$ ). As of now, there is no clear-cut mechanism or commitment to expand the SCO, and hence offer Iran or any other potential candidate any 
formal membership. Under the current circumstances, besides lack of norm setting, there seems some period of moratorium on new membership, due mostly to sensitivity as regards to political implications of an expansion. One argument may be posed that Kazakhstan, for instance, currently the third largest country in the organisation behind Russia and China, would lose some of its influence, as Iran or India joins.

The 2001 Declaration of Heads of States define the purposes of the SCO as: 'strengthening mutual trust and good-neighborly friendship among the member states; encouraging effective cooperation in political and economic spheres as well as in trade, scientific and technological, cultural, educational, energy, communications, environment and other fields; devoting themselves jointly to preserving and safeguarding regional peace, security and stability; and establishing a democratic, fair and rational new international political and economic order'. The SCO member states shall abide strictly by the purposes and principles of the Charter of the United Nations, mutually respect independence, sovereignty and territorial integrity of nations; non-interference in each other's internal affairs; no threat to use force against each other; adherance to equality and mutual benefit; resolution of all problems through mutual consultations. For the outside world, in the words of Chinese President Jiang Zemin, the organization will foster "world multi-polarization" and contribute to the "establishment of a fair and reasonable international order." (Associated Press, 15/6/2001).

The SCO Charter adopted at St. Petersburg summit in 2002 formally delineates institutional purposes and principles, organizational structure, form of operation, cooperation, orientation and external relations. The Charter lists a range of goals, from security and stability, fighting narcotics and terrorism, economic cooperation, cultural Exchange, to the promotion of democracy. Currently, the primary focus of the SCO is its 2001 Convention on Combating Terrorism, Separatism and Extremism, which commits member states to reciprocally extradite persons committing crimes and terrorist activities and to engage in multinational efforts to suppress and close borders to such elements. The Regional Anti-Terrorist Structure (RATS) was established in 2002 in Tashkent; yet, its anti-terrorist, anti-separatist, anti-extremist policies have somewhat led to concerns regarding the respect for civic and human rights. Meanwhile, apart from security considerations, new activity trends in the SCO framework are being actively explored, including promotion of economic ties- trade and investment; cooperation in areas of energy, transportation and transit; cultural and humanitarian exchange; rational use of natural resources and environmental protection. Council of Heads of State is the highest decisionmaking SCO organ. Of the SCO permanent bodies, the headquarters of SCO Secretariat is located in Beijing and SCO Regional Antiterrorist Structure (RATS) in Tashkent 'opened in January 2004. The 2006 summit in Shanghai appointed Bolat K.Nurgaliev to the post of SCO Secretary-General and Myrzakan U.Subanov to the post of SCO RATS Executive Committee Director as effective from 1st January 2007. 


\section{THE SCO TREADING IN THE FOOTSTEPS OF 'NATO'?}

What started as a confidence-building mechanism to resolve border disputes and to challenge separatism, the SCO member-states have agreed unanimously to elevate the organization of the 'Shanghai Five' to a "higher level" and expand its mission beyond the original objectives. As mentioned above, the new direction includes not only regional security, but areas such as regional economic development, commerce, and investment. For all members of the SCO, considerations of realpolitik, regional security, and parameters of political economy formed their justification for such an upgraded alliance or integration.

As a security pact, it is questioned by many whether the SCO possesses the characteristics of either the Warsaw Pact or NATO, or poses a fully-developed counterpart to the latter. Most experts subscribe to the view that the SCO can be conceived, at this stage, neither a "new Warsaw Pact." nor a mutual defense pact exemplified by NATO. For the Warsaw Pact, members in the past shared the same ideological/socialist values, a unified market under the Council for Mutual Economic Assistance, the same weaponary and defence systems, and an integrated command and control mechanism. The Pact permitted the Soviet troops and bases be positioned across the territory of its members, and had conducted joint military exercises. Under a single hegemonic power, the Soviet Union, the Warsaw Pact was able to moblize force, flex muscle, and conduct military operations at will.

Such capacities do not yet exist within the SCO. Given the SCO members' such cultural, ethnic and religious diversity, different levels of economic structure and development, divergent political aspirations, many regional challenges still unresolved, it is much too early to see if the SCO can mobilize itself to project a unified stand in form of a security alliance comperable to either the Warsaw Pact or NATO. As Plater-Zyberk $(2007,5-7)$ points out, in order to organise the $\mathrm{SCO}$ as a viable military bloc would require: political commitment (none of the current members sees the need for such an alliance); long term planning and coordination; a long-term, prohibitively expensive and well coordinated rearmament program.

Unlike the old Warsaw Pact, within such a loose institutional line-up as exists in the SCO, there is a sharing but not necessarily self-reinforcing exercise of power by the two regional heavyweights, China (the Dragon) and Russia (the Bear). The SCO's organizational effectiveness is also set to be hampered by internal frictions, tensions, and even competition between its member states over many challenging issues, such as minorities, border security, energy, pipelines, water resources in the region. On the other hand, those Central Asian states that are member of the club are too sensitive to assert their national identity, sovereignty, and independence, with simmering fear and suspicions as regards to the Bear and the Dragon. It needs to be noted that all five Central Asian nations have links with outside powers, being also participants of NATO's Partnership for Peace program. On the other hand, Kyrgyzstan's recent decision 
to close the Manas airbase, the only U.S. base in Central Asia, a vital transit point for NATO and U.S. operations signal serious turn of events.

At this point in time and also for the near future, many scholars views that the Shanghai Cooperation Organization is far from a replica of NATO and a "counterweight" to NATO, as it lacks the mechanisms, institutional depthness, organizational effectiveness, mutual trust, and common ideals. Unlike NATO, there are no declared commitments and mutual defense pledges. Given its structural evolution and working experience, its unprecedented enlargement over the post-Cold War period, the case of NATO can not to be easily emulated by the SCO or others. The SCO's multilateralism and characteristic of an alliance will not match that of NATO.

While fighting against extremism and terrorism is shared objectives, it is to be noted that the overall strategic aim of the alliance for Beijing and Moscow is somewhat geared to curb growing influence of the United States in Central Asia by way of establishing a joint sphere of influence at the backyard as well as across the continent (Cohen,1999; Wishnick, 2003; Cornell, 2004; Oliker and Shalpak, 2005; Weitz, 2006; Chin-Hao, 2006; Rumer, 2006; Olcott, 2006a; Schneider, 2008). Evidently, while resetting its priorities, the idea of counterbalancing the presence of the United States and hence that of NATO (actively involved in Afghanistan) in Central Asia has become one of the Organization's central objectives. Indeed, expansion of United States' influence in Central Asia made both Russia and China intimately concerned; both shared a need to check the U.S.'s enhanced position (Sangtu, 2008, p.156). Some commentators point out that a stronger SCO, particularly one with a military component and Iran as a full member, might serve as a check to U.S. interests and ambitions in the region Olcott (2006a; 2006c), while some others argue that the SCO lacks the power and economic strength to counterbalance the US (Cohen, 2006).

Some studies bring attention to the close relations between SCO and the Collective Security Treaty Organisation (CSTO), a purely military alliance, led by Russia. The origin of the CSTO is a treaty for collective security (CIS Collective Security Treaty, CST), which was signed in Tashkent in May 1992, within the framework of the CIS. In 2002, the six remaining CST parties signed a charter, which transformed the CST into the CSTO. The CSTO has at its disposal a joint headquarters in Moscow and a collective rapid reaction force. As essential elements of a professional security organisation, such rapid reaction forces and a military assistance article are part of the framework of the CSTO. Another Russian initiative adopted in 2007 was the foundation of a joint military force for peacekeeping operations. On 5 October 2007, during a CIS summit in Dushanbe, the signing of the MoU between SCO and CSTO finally took place. Therefore, in the near future, joint SCO-CSTO action may possibly develop. If the SCO will endeavour to proceed on a way towards a full-grown security organisation, then closer ties with the CSTO would be anticipated (de Haas, 2007, 24). 
It can not be denied that the SCO has achieved considerable headway as a international organization. As aptly stated by Bailes (2007), its progress faster than anything else so far - including NATO's partnership framework - in getting the Central Asians to work together on real issues in a non-zero-sum equation. It needs to be noted that the Central Asian members' participation in the SCO has by no means precluded their cooperation with NATO. Most experts agree that the SCO's influence in the region is on the rise. In conjunction with NATO, Feigenbaum (2007) makes the point that while the Shanghai Cooperation Organization is not "counterweight to NATO", the SCO's achievements as a multilateral security alliance will surely contribute to the overall security and stability of the region as a whole. It serves as a forum to minimize the possibility of direct confrontations in post-Cold War environment. Given the confidencebuilding mechanism established, the SCO should be able to avert conflicts between the two giants' overlapping interests and influence in Central Asia.

The SCO's stance declares to the international community that there is no "vacuum" in Central Asia's strategic space that needs to be filled by security organizations from outside the region. By way of holding its large-scale military exercises code-named "Peace Mission 2007", from August 9-17, held in Chelyabinsk in Russia's Volga-Ural military district and in Urumqi, capital of Xinjiang Uyghur autonomous region, the Organisation somewhat displayed solidarity and joint capability. As the SCO member countries other than China are already members of the CSTO, the proposed formal link between the CSTO and the SCO, which means the CSTO plus China, forms the construction of a new security architecture in this important part of the world space. The CSTOSCO nexus reinforces Russian efforts in "containing" NATO to the southwestern fringes of Eurasia. Chinese interests are well served by these past and present Russian efforts. From the point of view of both Russian and Chinese policymakers, the SCO was and is a way to maintain the strategic SinoRussian dominance over the wider Central Asian region, while engaging in friendly relations with their Central Asian neighbors (Yom, 2002; Snyder, 2008).

\section{CO-HABITATION OF THE BEAR AND THE DRAGON}

Noting that the SCO during the summit of 15 June 2001 forcefully underlined its right to regulate affairs in Central Asia, this alone signifies the single common ground where Moscow and Beijing interests can always converge. These two regional hegemonic states, which have defined terrorism, separatism and extremism as major threats to internal, regional and global stability, have politically subscribed pragmatic neo-realism, based on a firm defense of national interests, realpolitik worldview with a strong economic emphasis. Yet, their ambitions also seem to prevail for the establishment of a new world order, based on multipolarity, challenging the US-led structure in international order. (Berger 2008). Through the manipulation of the SCO, both nations know that they can raise their bargaining power vis-à-vis the U.S. and Europe, as well as all the regional states, including the post-Soviet independent states, Japan and Taiwan, by speaking and acting in concert. 
While swings and uncertainties characterized the Sino-Soviet relationship in the Cold War era, Sino-Russian relationship has steadily stabilized in the new century. Today, their respective interests have tended to converge more and more, as they are aware of the fact that it is not possible to realize those national interests without a healthy relationship 'solidarity' with each other (Yom, 2002; Norling, 2007). It is an accepted fact that the Bear and the Dragon nurture conflicting aims and interests regarding the region in general and the Central Asia in particular (Oldberg, 2007, 25-34). But, it is not to be forgotten that, at the basis, SCO is a Dragon project. The decision to locate SCO's headquarters in Beijing and to appoint a Chinese Secretary-General reflects an unchallenged Chinese influence. These administrative mechanisms have given the Chinese government much greater advantage over access to SCO decisionmaking.

China and Russia have reached a settlement of their 4,300-km shared border, trade has increased six-fold during Putin's term as president. Both powers support non-interference in domestic policy and thus seek internal stability. Beijing needs energy, arms, and raw materials in the pursuit of its industrialization, Moscow is in dire need of foreign investments to maintain internal and regional energy infrastructure and explore new energy discoveries, which can be readily funded by China. Russia needs backing in keeping its 'near-abroad' within its orbit and away from the Western penetration, Beijing wants to expand Xinjiang and beyond. While sharing economic benefits, they have vested interests in using Central Asian states as buffers and in containing insurgency, separatism, radicalism, and opposition.

While China's and Russia's interests seem to converge on a number of issues related or unrelated to US policies, there are areas of inevitable tension and conflict between the two powers (Torbakov,2007; Norling, 2007). Russian policymakers realise that a rising China will become a steadily stronger neighbour, as in the case of Taiwan, keen to address those "red line" territorial issues, going far back to times of Tsarist Russia. It is more of a clash of longterm interests and competition for greater domination and slicing of greater portion from the Central Asian pie. As Torbakov configures, China is set to establish its hegomony in the region, while Russia has to struggle hard to maintain its strategic standing on par with China (Torbakov, 2007,12).

Among so many serious sources of tension, one obvious is the ongoing large immigration of Chinese into the Russian Far-East and untapped resource-rich Siberia ("Sinocization" of the area), which is a threat not only for Russian Federation (also a threat to densely populated Kazakhstan). Both are also competing for their share of overland continental trade from East Asia to Europe, either via the Trans-Siberian railway or on the second Euro-Asia landbridge running via Xinjiang and Central Asia, as well as matters regarding pipeline routes and energy management.

At the macro level, given its unrelentless high economic growth, Chinese economy will be able to catch the U.S. economy by 2015 . At the backdrop of 
growing trade relationship between China-Central Asia, and China-Europe, and China-U.S. , thereby power asymmetries growing, Russia will trail well behind, losing its economic position and attraction. Morever, Beijing's increased partnership engagement with New Delhi, Islamabad, and Tehran will directly undermine Russia's clout and spheres of influence. Russia's principal advantage it possesses over China is energy; but as China makes inroads into Central Asia through bilateral agreements with namely with Kazakhstan and Ozbekistan, and acquisitions of assets, Moscow's ability will be eroded. With power-relations reversed, China wiil be becoming the dominant power. As Norling puts bluntly, Russia needs China more than China needs Russia (Norling, 2007; Torbakov,2007).

Long after the original nineteenth-century great game between Czarist Russia and the United Kingdom, Russia still remains in the region as a hegemonic power. But this time, there are more international actors active in the game than before. As the governor of most of this region for over a century, Moscow has long historical and cultural ties and subscribes to a strong conviction that Central Asia is its sphere of influence. However, the past 15 years have seen its military and diplomatic strength in the region wane, drained by difficulties of transition, the war in Chechnya, and problems of sustaining its large, Sovietlegacy military. A resurgent Russia under Vladimir Putin has been more closely engaged than anytime and any other external actor with regards to events and geopolitics in Central Asia. As mentioned above, Russia's one added advantage is that it is involved as the dominant partner in a number of multilateral organizations within the region, such as the CIS and the CSTO. In comparison to the SCO, Moscow wields much greater influence, through which it is able to project relatively more power.

Moscow's multiple objectives are reasserting Russian dominance, securing Russia's vulnerable southern borders against threats, checking Islamic extremism and ethnic tensions. Russia has secured military presence and closer security links with the Stans: Kyrgyzstan, Kazakhstan, Tajikistan, Uzbekistan, and Turkmenistan, and continues to prop up its defense activities in the area. Despite China's growing commercial presence in the region, Russia also remains Central Asia's leading business partner. Moscow is an active participant in developing the region's natural resources, undertaking commercial, managerial, and technical services in many Central Asian communities. Of course, the political and economic influence that Russia exercises stems from the Soviet institutional infrastructure and apparatus of its past and the current pivotal role in Central Asia 's energy networks. Central Asian oil and gas exporters continue to use Russian pipelines. Central Asia's landlocked states continue to rely heavily on transportation, communications, supply-chain, and other facilities that somewhat directly or indirectly come under Moscow (Weitz, 2006, 2-3).

Later in Putin's era, Russian foreign policy started to change towards a less Western-oriented and more Central Asia-China-focused foreign policy from 
2002 onwards. Instead of bandwagoning with the U.S., the Kremlin chose to shift its attention to a Russo-Chinese balance, that Russia perceived no tangible benefits from the deepened engagement with Washington. For Moscow, in reaction to "color revolutions" in the post-Soviet space, NATO's expansion into the Baltics, and permissions given to the U.S.'s bases in Eastern Europe, it became priority to reassert control over the state apparatus (primarily in the energy sector), Russia's periphery in its "near abroad" in Central Asia and the Caucasus.

Chinese share many anxieties and similar important goals with Russia as far as the membership of the SCO and the viewing of Central Asia is concerned. At the general level, they have found co-habitation with Moscow benefical, as they are able to benefit from Russian initiatives in these areas and redirect resources to other priorities. As a matter of fact, because of its ability to mobilize and hence to rely on Chinese support, Russia's once cooperative attitude toward the U.S. changed into one of deterrence. The strategic partnership between the two would undermine the U.S. involvement in the region (Dongfeng, 2003; Cohen, 2006; Ollcott, 2006a; Nichol, 2007). Similar to Moscow, Beijing is concerned about the spread of threatening ideologies such as Western democracy and Islamic fundamentalism. Likewise, the growing presence of the U.S. in the region and the Far East has aroused fears of encirclement and containment for Beijing, driving to protect its western flank from intrusion from foreign powers. But unlike Moscow, Beijing so far has avoided directly challenging the U.S.military presence in Central Asia, while recognising the advantages of having the United States as partner vis-a vis the fight against terrorism and promoting stability - sine qua non to develop Central Asian oil and gas resources. (Weitz, 2006,p.5). In the construction of the SCO, undisturbed by the fact that Russia has successfully improved its strategic position in the region, Chinese leaders have engaged Russia in Central Asia and have undoubtedly favored a preeminent security role for Moscow-as a hedge against the growth of Islamic radicalism and US presence (Yom, 2002; Walt 2003; Chung 2004a, 2004b).

For Beijing, beside security considerations, which incorporate military influence in Central Asia, the rise of political and economic clout in the region occupies top priority. The most important goal is being to reach out energy resources therein, along with securing markets for its goods, and outlets for investment. China's growing energy needs-presently being the world 's second-largest oil consumer- represent principal driving force for increased interest and involvement in Central Asia. In order to secure diverse sources of energy and the pending risks and vulnerabilities of the Persian Gulf supplies of oil, China is pushing for the development of alternative land-based oil and gas pipelines that would secure the flow of Central Asian gas and oil supplies eastward toward China. The Chinese west-east pipeline projects are going hand in hand with active operations of Chinese oil and gas companies, which are busy in launching joint ventures or direct acquisitions in energy projects in Kazakhstan, Turkmenistan, and Uzbekistan. They continue to acquire energy assets and buy 
up other strategic natural resources and industries, as and when these become available, and with so much surplus capital they possess. In the long run, however, such a development would no doubt undermine the Russian hegemony of directing and operating the westward flow of energy resources (Cohen, 2006; Olcott, 2006b, 2006c; Oldberg, 2007; Germanovich, 2008; Marketos, 2008).

Beijing seeks to get tacit approval or non-interference in its struggle against ethnic separatistism in the Turcic Uyghur autonomous region of Sinxjang province. As for Moscow, it has allied with Beijing in order to restore some of its influence over its "near- abroad" and reassert its regional hegemony. While trying to keep away the U.S. and its NATO allies from the region, the SCO can facilitate control of Chinese intrusion. The regimes of the Central Asian states want support for their survival against opposition movements, economic development assistance, and increased trade and investment. Flow of Chinese investment and finance for infrastructure and development in and across Central Asia will potentially contribute to prosperity, under the watchful eyes of Moscow. Growing regional prosperity will mean peace, an environment less amenable for outside intervention.

As argued by Chung (2004a; Chung 2004b), Beijing has three reasons for wanting to minimize U.S. hegemony the region. Firstly, China fears that, with an American ally in their midst, Central Asian states will pay less heed to Chinese political demands than before. Secondly, China worries that efforts to augment its economic influence in Central Asia will be compromised by U.S. support for American petroleum companies in winning concessions from regional governments at China's expense. Thirdly, with military bases close to China's western borders, Washington has the option of helping Beijing flush out Xinjiang terrorists operating in Central Asia, or putting direct military pressure on China if it perceives a threat from that country. In that respect, the U.S. military presence retarded progress in institutionalizing the $\mathrm{SCO}$, and surging Chinese influence in Central Asia kept under check. China's short term concerns were initially focused on border delineation issues, and minimizing direct and indirect involvement by the Central Asian states in China's own ethnic minority issues. Over time, as a result of deepening level of security cooperation, largely through the evolving SCO, there has been a growing Chinese focus on economic agenda, most particularly in the area of energy in the region Olcott $(2006 \mathrm{~b}$; Cohen, 2006).

The question remains what exactly the relationship between two huge continental powers- Russia and China- is going to be like. Mutual distrust has always characterized relations between Russia and China at the diplomatic and military levels, and mutual exploitation is likely to increase in their bilateral relations. China and Russia are not likely to become genuine military allies. For the two leading actors of the SCO, Moscow and Beijing, the geopolitical competition in Central Asia is not a zero-sum game. The issue of energy, that of oil and gas, would work as a dividing factor. Under Putin, China and Russia 
have grown much closer, bound by their mutual distrust of U.S. hegemonic unilateralism and their perceived need to promote a multipolar world. With its abundant but high cost energy reserves, Russia will be after high oil prices, that means it will welcome Middle East instability. China, on the other hand, has an almost insatiable demand for energy on which its present economic growth depends. Thus, Beijing, eager in the building of a pan-Asian transportation corridor (the Silk Road) from the Far East to Europe and the Middle East, is interested in keeping the price of oil as low as possible and the commodity flows including oil to and from the Middle East unhindered.

\section{THE STANS WHERE THEY DO STAND}

The SCO's Central Asian membership commands a combined population of over 55 million (Uzbekistan followed by Kazakhstan) and a land mass greater than Western Europe.The disintegration of the USSR in December 1991 and emergence of the newly established independent states in Central Asia and the Caucasus generated opportunity for all interested parties to indulge in power projection. Of these players, the two neighboring countries, Turkey and Iran, which have ethnic and regional ties with the Central Asian states, ardently competed to have influence in the region. But neither has been able to exert influence comparable to that of Russia and China, after burst of enthusiasm in the 1990s.

Moscow has kept one step ahead in the race because of bilateral relations with Russia remained and still remain important for most Central Asian states, due to a number of historic and geopolitical facts. Of course, Moscow-centricity dominates the thinking of political elites and the work of bureacracy brought up in the former Soviet system. Russia's proactive foreign policy to regain its former hegemonic power in this region deterred both Iran and Turkey from playing more active role in Central Asia. To a certain extent, on the strategic level, Iran favored the Russians to maintain its strong position on the newly independent Central Asian states in order to prevent penetration of the U..S as well as Turkey into the region. In their joint opposition to any Turkish influence in the area, Iran and Russia also have forged a strong military alliance in terms of supplying weapons and building nuclear plants. Iran's intention to transform the SCO into a security group in opposition to the U.S. and NATO seems, however, one of major obstacles in front of Iran's prospective membership to the SCO, Above all, Iran's nuclear crisis with the West stands the biggest handicap (Maksutov 2006, 87-95).

As mentioned above, the interests of Central Asian members in the SCO are manifold and may be divergent. Yet, their common grounds to join the Organisation can be identified as many: nation building- securing independence, non-interference and sovereignity; national security, protection of borders from internal and external threats; good neighbourly relations; control over and effective utilisation of natural resources; enhanced trade and commercial dealings; access to world commodity and capital matkets; 
establishment of national and regional infrastructure for transport and communications (Linn, 2007). They are clearly most 'interested in the SCO 's practical undertakings for regional security and development such as confidence-building, anti- terrorism activity, fighting drug trafficking and securing borders, trade and economic cooperation, investment projects, rehabilitation of transportation networks and exploitation of transit potential' (Maksutov 2006; Linn 2007).

Irrespective of being member or non-member of the SCO, Central Asia nations are exposed to the potential dangers of falling into the orbit of Chinese or Russian domination, despite their 'balancing' efforts based on multi-vector foreign policy. It may be observed that Central Asian membership of the SCO clearly weakened the appeal and potentials of another regional formation, with which they have had much closer and earlier affinity. That is the Economic Cooperation Organization (ECO), an intergovernmental regional organization established in 1985 by Iran, Pakistan and Turkey for the purpose of promoting economic, technical and cultural cooperation among members. the ECO is the successor organization of Regional Cooperation for Development (RCD) which remained in existence since 1964 up to 1979. ECO was later joined by of Afghanistan, Azerbaijan, Kazakhstan, Kyrgyzistan Tajikistan, Turkmenistan, Uzbekistan, in the aftermath of the collapse of the Soviet Union. The Organisation's membership has a population of 400 million, with a cumulative GNP of $\$ 1,354$ billion (2006-2007), and covers an area of $8,620,697 \mathrm{~km} 2$,, larger than Western Europe.

In fact, the eager efforts of the founding members of the ECO, like Iran, Pakistan, and Turkey individually to become observer or full member of the SCO is seen paradoxical, as such a move is bound to have adverse effects on the former. Positions in favour of SCO will be seen to undermine the weight and dynamic prospects that ECO, a more experienced regional institution, would have developed over time. At the game, Ankara, in particular, had envisaged its own idealistic vision of Turcic world, spanning from Adriatic coast to Xinjiang; it was also a modelling project, which did not get off the ground basically due to Turkey's preoccupation with the membership of the European Union- that is looking Westward .In totality, reactive strategies (or rather 'bandwagoning') of Iran, Pakistan, and Turkey as well as of those Central Asian states would leave ECO in doldrums, contributing to the consolidation of SCO, by way of demonstrating the futulity of efforts and aims made under the former. ECO is set to lose its power of gravitation, if any, as Central Asia's political and economic future would be governed by three primary vectors: Sino-Russian coalition, U.S. interests in the region, and the upbeat of Islamist militancy.

\section{CONCLUDING REMARKS}

Central Asia has become an area of suddenly heightened strategic concern to the major Asian and Western powers. The present time now appears as another 
episode of drawn-out and unfinished struggles over Mackinder's geography. Undoubtedly, the recent times have witnessed the resurgence of the traditional "great game" among the major external players in the region. The SCO is positionned as a potential powerhouse engaging the attention of the neighbors across the Asian continent to join, and keeping external powers out of Central Asia.

Projecting as the largest regional organisation in terms of both land mass and population, the geo-strategic potential of the SCO cannot downplayed. it is a forum which has so far succeeded to bring together the two major powers Russia and China plus their client energy-rich Central Asian neighbours. The aim of counterbalancing the U.S.-NATO presence in Central Asia, particularly in the aftermath of September 11, has so far being the main driver that has led the two regional powers to set aside their diverging political and ideological ambitions. However, over time, neither China nor Russia will be willing or comfortable in letting the other to dominate the organisation on its terms. For the third party, cornered by these two regional powers, the Central Asian states 'Stans' will endovour to preserve their national identity and sovereignty through pursuing balancing acts or multi-vector policies. They will thread cautiously so to deal with Moscow's and Beijing's long term policies and regional ambitions, particularly when it comes to the utilization of energy reserves and natural resources. It remains to be seen whether the converge of interests of such disparate members can be sustained in the years ahead so as to make the SCO an powerhouse- hence facilitating the elevation of Russia's and China's international profiles. At this juncture, the possible membership of Turkmenistan willl turn out to be a real test.

The future depends on so many parameters, mainly or mostly on how China, at the driver seat, can carefully navigate through the troubled waters where so many fishing fleets are out to catch much as how the other principal players will act or react in this power equation. Much also depends on how the SCO's smaller, but nonetheless fiercely nationalistic Central Asian members' relationship with Russia and China would proceed. For the present, the Central Asian typically authoritarian leadership appears convinced that their immediate and future security concerns and economic interests are better served by the Moscow-Beijing Incorporation, noting that they all share a border either with Russia or with China. They, notably Kazakhistan, will certainly, be keeping the option of partnership with the West i.e. NATO's Partnership for Peace and close economic ties open. The 'balancing' will be done through 'multi-vector' foreign policy of maintaining good relations with all the large actors in the international arena.

The SCO stands poised to become influential in Central Asian politics. At the present, for the international power game, the SCO is however less than a full powerhouse to reckon with. Its clout will rise and diminish in line with Chinese interest in the project. China has so far proved willing to pour substantial diplomatic and economic resources into this long term project. With the Central 
Asian republics badly in need of economic and political support, their loyaltiesthe national interests- will follow money. China's interest in the region and willingness to flex its diplomatic muscle are also growing rapidly. In this equation, being yet a significant player, Russia lacks the economic financial resources and the manpower to mobilize as well as the diplomatic sophistication to lead the organization.

For the outsiders, those observers or non-observers, like Turkey, they have to watch the game on play with some apprehension. Given an 'expanded' SCO and its control of a large part of the world's oil and gas reserves, growing economic power, and nuclear arsenal, except few, experts agree that the SCO's political military, and economic clout is on the rise, not only within the Eurasian space, but also as an international actor to be taken seriously. A stronger SCO, particularly one with a military (nuclear arsenal) component and Iran as a full member, will then become the third leg of the multipolar world order, let alone a paper tiger. Notably for Beijing, as for other members as well, an aggressive SCO would however run counter to the members vital interests benefits of cooperation with the West, if attempts proceed to transform the SCO into an anti-Western or anti-US/NATO block. The SCO should however be a conscious stakeholder contributing to stability, peace and prosperity in Eurasia; it should refrain from constructive engagament with the non-membership.

\section{REFERENCES}

Antonenko, Oksana (2007), "The EU the Shanghai Cooperation Organization, the London Centre for European Reform, April 2007, at www.cer.org.uk (Both available August $25 \quad$ 2007).http://srch.slav.hokudai.ac.jp/kaken/iwashita2007/01antonenko-eng.pdf

Austin, Greg (2002), "European Union Policy Responses to the Shanghai Cooperation Organization", European Institute for Asian Studies, Brussels. BP 02/04, December.

Bailes, Alyson.J.K. and P. Dunay (2007), The Shanghai Cooperation Organization, SIPRI Policy Paper no. 17, May 2007, text at http://www.sipri.org.

Bailes, Alyson J. K., and Pál Dunay, Pan Guang and Mikhail Troitskiy (2007), The Shanghai Cooperation Organization, SIPRI Policy Paper no. 17 (Stockholm International Peace Research Institute, May 2007), available at http://books.sipri.org.

Baev, Pavel K. (2004), Assessing Russia's Cards: Three Petty Games in Central Asia, Cambridge Review of International Affairs, Vol 17, No 2, July , p.269-283.

Beehner, Lionel and Preeti Bhattacharji (2008), The Shanghai Cooperation Organization, Backgrounder, April 8, the Council on Foreign Relations, http://www.cfr.org/publication/10883/. 
Berger, Heidi. (2008), "The Roles of the Shanghai Cooperation Organization (SCO) and Regional Antiterrorist Structure (RATS) in the Fight against Terrorism and other National Security Challenges within the Framework of Russia - China Relations" Paper presented at the annual meeting of the ISA's 49th Annual Convention, Bridging Multiple Divides, Hilton San Ffrancisco, San Francisco, California, USA, March 26.

Bhadrakumar, M K "Shanghai Cooperation Organization Primed and Ready to Fire: Toward a Regional and Global Realignment?", Japan Focus.org.

Blank, Stephen (2006), Strategic Surprise? Central Asia in 2006, China and Eurasia Forum Quarterly, Vol. 4, No. 2, p.109-130.

Brummer, M. (2007), "The Shanghai Cooperation Organization and Iran: A Power-Full Union", Journal of International Affairs, Vol.60, No.2, p.185-200.

Brzezinski, Z. (1997), The Grand Chessboard: American Primacy and Its Geostrategic Imperatives, New York: Basic Books, p.34-42, p.78-91.

Chung, Chien-peng (2004a), "China's Influence in Central Asia and the Shanghai Cooperation Organization: On the Defensive?" Paper presented at the annual meeting of the International Studies Association, Le Centre Sheraton Hotel, Montreal, Quebec, Canada, Mar 17. Available. 2008-10-10 http://www.allacademic.com/meta/p74237_index.html

Chung, Chien-peng (2004b), "The Shanghai Co-operation Organization: China's Changing Influence in Central Asia." , The China Quarterly, Vol. 180, December, 989-1009.

Cohen, Ariel (1999), 'U.S. Interests in Central Asia', Testimony before the Subcommittee on Asia and the Pacific / House International Relations Committee - United States House of Representatives, March 17.

Cohen, Ariel (2006), "The Dragon Looks Qwest: China and the Shanghai Cooperation Organization", Heritage Lectures, No 961, August 3, The Heritage Foundation, Washington DC.

Cornell, Svante (2004), "The United States and Central Asia: in the Steppes to Stay?”, Cambridge Review of International Affairs ,17, 239-254.

Cotter, Michael W. (2008), "The New Face of Central Asia", Caucasian Review of International Affairs, Spring.

Çolakoğlu, Selçuk (2004), "Şanghay İşbirliği Örgütü'nün Geleceği ve Çin", Uluslararası Iliş̧kiler Dergisi, Cilt 1 Sayi 1, Bahar ( Vol 1/1, Spring), p. 173-182.

de Haas , M. (ed.) (2007), The Shanghai Cooperation Organisation: Towards a full-grown security alliance?, Clingendael Security Paper 3, The Hague, 
Clingendael Institute, November. http://www.clingendael.nl/ publications/2007/20071100_cscp_security_paper_3.pdf.

Dodds, Klaus and James D.Sidaway (2004), Halford Mackinder and the 'geographical pivot of history': a centennial retrospective , The Geographical Journal, Vol. 170, No 4, December, p. 292-297.

Dongfeng, Ren (2003), " The Central Asia Policies of China, Russia, and the USA, and the Shanghai Cooperation Organization Process: a view from China", accessible at http://editors.sipri.se/pubs/ Central AsiaSCO.pdf, (e.t. 01/04/2006).

Erol, Mehmet Seyfettin and Çigdem Tunç (2003), "11 Eylül Sonrası ABD'in Küresel Güç Mücadelesinde Orta Asya" The Cenral Asian in US Avrasya Dosyası, Küresel Değerlendirme Özel, Sohbahar, Cilt: 9, Sayı 3, s. 5-28.

Feigenbaum, Evan A. (2007), "The Shanghai Cooperation Organization and the Future of Central Asia" ,September 6, The Nixon Center, Washington, DC. Public Statements on South and Central Asian Policy. http://www.state.gov/p/sca/rls/rm/2007/91858.htm

Germanovich, Gene (2008), The Shanghai Cooperation Organization: A Threat to American Interests in Central Asia?", China and Eurasia Forum Quarterly, Vol. 6, No. 1, p.19-38.

Gill, Bates, and Matthew Oresman (2003), "China's New Journey to the West: China's Emergence in Central Asia and Implications for U.S. Interests." CSIS Report: CSIS, August, Washington DC.

Huang Chin-Hao (2006), "China and the Shanghai Cooperation Organization: ost-Summit Analysis and Implications for the United States." The China and Eurasia Forum Quarterly, Vol. 4, No. 3. August.

Jones, Gareth (2005), “Turkey's Plan B? Turks rediscover Central Asia” , 05 Temmuz 2005 article accessible at http://www.turksam.org/tr/a163.html

Kalra, Prajakti and Siddharth S.Saxena(2007), "The Shanghai Cooperation Organization and Prospects of Development in the Eurasia Region", Turkish Policy Quarterly, Volume 6, No 2, p.95-99.

Kennedy, Paul (2004), "The pivot of history- the US needs to blend democratic ideals with geopolitical wisdom", the Guardian newspaper, 19 June.

Linn, Johannes F. and David Tiomkin (2005), Economic Integration of Eurasia: Opportunities and Challenges of Global Significance, paper presented at the Center for Social and Economic Research in Warsaw on April 8-9, No 298 accessible at http://www.case.com.pl/ 
Linn, Johannes F. (2007), "Central Asia-National Interests and Regional Prospects", China and Eurasia Forum Quarterly, Vol.5, No.3, p 5-12.

Macfarlane, S. Neil (2004), "The United States and regionalism in Central Asia", International Affairs, 80,3, p.447-461.

Mackinder, H.J. (1904), "The geographical pivot of history". Geographical Journal , 23, 421-444.

Maksutov, Ruslan (2007), "The Shanghai Cooperation Organization: A Central Asian perspective", SIPRI, August 2006, text under "Project Papers" at http://www.sipri.org/contents/worldsec/eurosec.html (August 27 2007).

Marketos, Thrassy N. (2008), China's Energy Geopolitics The Shanghai Cooperation Organization and Central Asia, Routledge Contemporary China Series, Routledge, pp.184.

Menon, R. (2003) ''The New Great Game in Central Asia', Survival, 45(2), p.187-204.

Nichol, Jim (2007), Central Asia's Security: Issues and Implications for U.S. Interests, RL30294, CRS Report for Congress, Updated April 26.

Noi, Aylin Ü. (2006), "Iran and the Shanghai Cooperation Organization: is it possible for Iran to become full member of the Shanghai Cooperation Organization under pressure of nuclear issue?", Perceptions, Autumn - Winter, p.79-103.

Norling, Nicklas; Swanström, Niklas (2007), "The Shanghai Cooperation Organization, Trade, and the roles of Iran, India and Pakistan" Central Asian Survey, Volume 26, Number 3, September, p. 429-444.

Norling, Nicklas (2007), "China and Russia: Partners with Tensions" p.33-47 www.silkroadstudies.org/new/docs/publications/2007/Norling_China_and_Russi a.pdf

Norling, Nicklas; Swanström, Niklas (2007), "Sino-Russian Relations in Central Asia and the SCO", Central Asia-Caucasus Institute Analyst, 10/03/2007 issue, http://www.cacianalyst.org).

Olcott, M.B. (2003a) "Central Asia: Terrorism, Religious Extremism, and Regional Stabil-ity", testimony before the US House of Representatives, Committee on International Relations, Washington DC, 29 October.

Olcott, Martha Brill, (2006a), "U.S. Policy in Central Asia: Balancing Priorities (Part II)" Testimony Prepared for the House Committee on International Relations Hearing on the Middle East and Central Asia, April 26, 2006..to be 
accessed

at

http://www.internationalrelations.house.gov/archives/109/olc042606.pdf

Olcott, Martha Brill (2006b), "Is China A Reliable Stakeholder in Central Asia?", Testimony before the U.S-China Economic and Security Review Commission , August http://www.uscc.gov/hearings/2006hearings/written_testimonies/06_08_3_4wrts 106_08_3_4_olcott_martha_statement.pdf.

Olcott, Martha Brill (2006c), "The Shanghai Cooperation Organization Changing the "Playing Field" in Central Asia", Testimony before the Helsinki Commission September 26.

Oldberg, Ingmar (2007), "The Shanghai Cooperation Organization: Powerhouse or Paper Tiger”, Swedish Defence Research Agency, FOI-R-2301-SE, June, pp.60. http://www2.foi.se/rapp/foir2301.pdf

Oliker, Olga and David A.Shlapak, "U.S.Interests in Central Asia- Policy Priorities and Military Roles", Project Air Force, MG338, 2005 by the RAND Corporation.

Plater-Zyberk, Henry, (2007), "Who's afraid of the SCO" ,Conflict Studies Research Centre, Central Asian Series 07/09, March, accessible at http://www.defac.ac.uk/colleges/csrc/document-listings/caucasus-publications

Quingguo, Jia (2007), “The Shanghai Cooperation Organization:China's Experiment in Multilateral Leadership", p.113-123, accessible at http://www.irchina.org/en/pdf/jqgo7a.pdf.

Rumer, Eugene (2006), "The U.S.Interests and Role in Central Asia after K2", The Washington Quarterly, 29:3 ,Summer , p.141-154.

Sangtu, KO (2008), “Russia's Choice of Alliance: Balancing or Bandwagoning?, Slavic Eurasian Studies, No 16, p.149-161.http://srch.slav.hokudai.ac.jp/coe21/publish/no16_1_ses/08_sangtu.pdf

Shambaugh, David (ed.) (2005), Power Shift: China and Asia's New Dynamics, (Berkeley:University of California Press).

Shanghai Cooperation Organization, http://www.sectsco.org; Declaration on Establishment of Shanghai Cooperation Organization <http://www.sectsco.org/html/00088.html>.

Schneider, David K. ( 2008), "The Shanghai Cooperation Organization:A League of Autocracies", Global Policy Forum, September 16. http://www.globalpolicy.org/empire/analysis/2009/0916sco.htm 
Schneider, Michael (2008), "The Shanghai Cooperation Organization- A New Order in Central Asia", Stanford Journal of East Asian Affiars, Winter, p.16- 22, http://www.stanford.edu/group/sjeaa/journal81/CE2.pdf

Trenin, D. (2003) "Southern Watch: Russia's Policy in Central Asia", Journal of International Affairs, 56 (2), p.119-31.

Turner, Jefferson E. (2005), Shanghai Cooperation Organization: Paper Tiger or Regional Powerhouse?, Ph.D Thesis, Naval Postgraduate School, September, pp.146.

Walt, Stephen M. (2003) "Alliances: Balancing and Bandwagoning," in International Politics: Enduring Concepts and Contemporary Issues, 6th ed., eds. Robert J. Art and Robert Jervis (New York: Longman, 2003), p.111-113.

Weitz, R. (2006) , "Averting a New Great Game, in Central Asia", The Washington Quarterly, 29:3 Summer, p.155-167.

Wilson, Jeanne L. (2004), Strategic Partners: Russian-Chinese Relations in the Post-Soviet Era, Armonk: M. E. Sharpe, pp. .279.

Wishnick, Elizabeth (2003) "Growing U.S. Security Interests in Central Asia," Strategic Studies Institute, http://www.e11th-hour.org/archives/usinterest.pdf (e.t. 30/03/2006).

Wolfe, Adam (2005), "The 'Great Game ' Heats Up in Central Asia," August 3, http://www.pinr.com/report.php?ac=view_report\&report_id=339\&

language_id $=1$.

Yazdani, Enayatollah (2006), "Competition over the Caspian oil routes: Oilers and Gamers perspective", Alternatives: Turkish Journal of International Relations, Vol. 5, No.1\&2, Spring \& Summer , p.51-64.

Yom, Sean L. (2002), "Power Politics in Central Asia", Harvard Asia Quarterly, Vol.VI, No.4, Autumn. http://www.asiaquarterly.com/content/view/129/1/

Yuan, Jing-dong (2004), "China and the Shanghai Cooperation Organization: Charting a New Course for Regional Cooperation?" Paper presented at the annual meeting of the International Studies Association, Le Centre Sheraton Hotel, Montreal, Quebec, Canada, Mar 17. 